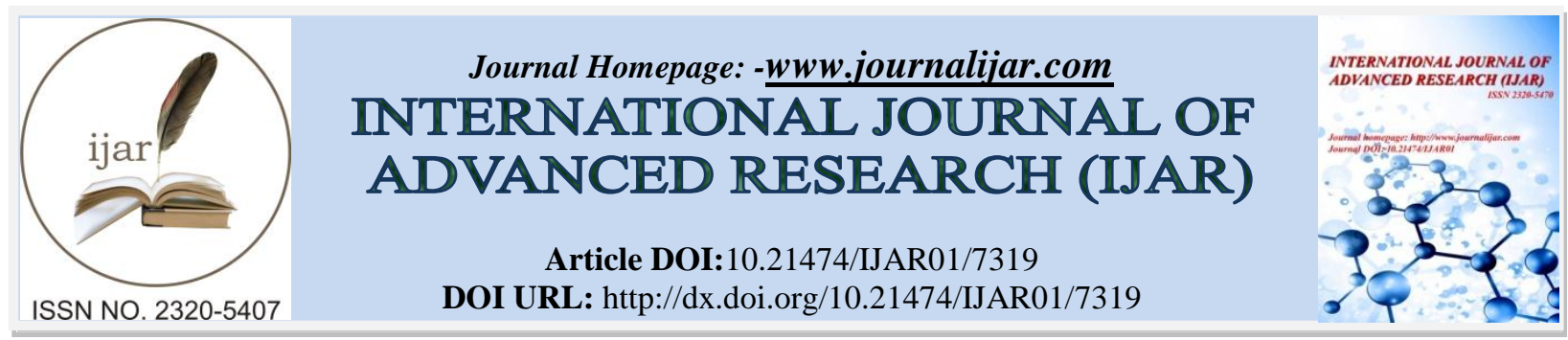

RESEARCH ARTICLE

\title{
HYDROCHEMICAL APPRAISAL OF GROUND WATER QUALITY AND ITS WATER QUALITY INDEX: A CASE STUDY IN MATHURA DISTRICT, INDIA.
}

\author{
Salman ahmed ${ }^{1}$, shadab khurshid ${ }^{1}$, ali p. Yunus ${ }^{2}$ and sanjay kumar koli ${ }^{3}$. \\ 1. Department of geology, Aligarh Muslim university, Aligarh 202 002, India. \\ 2. Department of Remote Sensing and GIS Applications, Aligarh Muslim University, Aligarh 202 002, India. \\ 3. Ch. Brahm Prakash Government Engineering College.
}

\section{Manuscript Info}

Manuscript History

Received: 19 April 2018

Final Accepted: 21 May 2018

Published: June 2018

\begin{abstract}
This study focuses on groundwater quality analysis using analytical and geographical information system (GIS) for prospecting suitable groundwater sites in Mathura district for drinking and irrigation purposes. Physio-chemical parameters of major ions for the 65 locations of water samples collected from March 2016 through September 2016 have been experimentally determined and evaluated by comparing their values with World Health Organization (WHO), Bureau of Indian Standards (BIS) and Water Quality Association (WQA). Results show that Total Dissolved Solids (TDS), Total Hardness( $\mathrm{TH}), \mathrm{Mg}^{2+}$ and $\mathrm{Cl}^{-}$are found to be higher than (>50\%) the permissible limit when compared with the guidelines of the WHO, BIS and WQA. The piper trilinear diagram shows the majority of the groundwater samples are Na-K type. The spatial distribution of various physio-chemical parameters were also plotted in the GIS environment to determine suitable groundwater prospecting sites for drinking and irrigation. The resultant integrated water quality map shows that except for some parts of the north-west Mathura and Southern region, water quality in the Mathura district is largely unsuitable for drinking and irrigation purpose. Water quality index shows that the maximum area of the Mathura district is unsuitable for drinking.
\end{abstract}

Copy Right, IJAR, 2018,. All rights reserved.

\section{Introduction:-}

Formed in the downstream of Ganges and Brahmaputra river system, the Indo Gangetic basin (IGB) aquifer system is one of the important freshwater resources in the world (McDonald et al. 2016). The fertile Indo Gangetic basin ranks one of the most densely populated regions and it supports the livelihoods of more than 400 million people. With increased population growth and intensified agriculture practices, a large number of water wells are abstracting ground water from the IGB aquifer system. McDonald et al. (2016) indicate that the increasing groundwater extraction in IGB leads to groundwater depletion in localized areas and the threat of contamination is severe. According to their studies, water table levels are falling in urbanized centers and further extraction in these areas are not sustainable. 
A deterioration in groundwater quality is because of many reasons. The primary being excess withdrawals without sustainable planning. Other reasons include the impromptu development of urban areas. Spillage of sewage through broken or faulty infrastructure, aimless transfer of domestic and industrial waste into the ground, incursion of saltwater and improper utilization of agro chemicals being the other reasons (Todd 1980; Hem 1991; WHO,2006; Subba rao, 2008). Nevertheless, the aquifers are influenced by many other processes, including wet and dry depositions of atmospheric salts, evapotranspiration, and soil-water-rock interactions. Climate change adds more to the existing problem. Increased variability in monsoonal dynamics along with more extreme weather conditions such as heat waves and droughts have intensified. As a result, IGB has seen drying up of surface water resources upon which people depend for irrigation to grow their food in the $21^{\text {st }}$ century. Having faced shortages in quality water for drinking and irrigation purpose, people start searching for suitable groundwater sites. Analysing the hydrochemistry of groundwater to assess the quality is primary for determining its use for drinking and irrigation purposes (Logeshkumaran et al. 2015).

Because freshwater sustains life, a large number of studies have focused on groundwater quality research that has been impacted by natural causes as well as human intervention. Contemporary studies on water quality research relies extensively on analytical techniques, isotopic measurements, numerical modelling and remote sensing techniques coupled with GIS models $(\mathrm{Li}, 2016)$. Several studies have found that contaminated groundwater can harm humans and plants (Bhutiani et al. 2016; El-Salam and Abu-Zuid, 2015). Arsenic contamination in groundwater has been well documented in IGB and other parts of India and Bangladesh (Chakraborti et al. 2009 ). Physio-chemical characteristics of groundwater such as $\mathrm{pH}$, total dissolved solids (TDS), magnesium (Mg), sodium $(\mathrm{Na})$, iron $(\mathrm{Fe})$, calcium $(\mathrm{Ca})$, manganese $(\mathrm{Mn})$, lead $(\mathrm{Pb})$, nitrate $\left(\mathrm{NO}_{2}\right)$ and nitrite $\left(\mathrm{NO}_{3}\right)$, and bicarbonate levels $\left(\mathrm{HCO}_{3}\right)$ have been intensively studied for measuring and understanding the quality of water. The concentrations of salts are related to the specific conductivity of water along with the related proportion of bicarbonates to calcium and magnesium. When salts are present beyond a certain limit in water and used for drinking or irrigation, such water harms human health and plant growth (Purushotham et al., 2011).

A water crisis in Mathura district, Uttar Pradesh, India has aggravated recently due to the drying of surface water and depletion of groundwater levels. The over abstracting of groundwater for irrigation and improper fertilizer practices leads to salt intrusion, soil salinization and importantly contamination. This study attempts to identify potential groundwater prospect zones that are safe for drinking and irrigation in Mathura district by employing analytical techniques and GIS.

\section{Study Area:-}

Mathura, one of the most populated district ( $2.5 \mathrm{bn}$ ) in Uttar Pradesh, India is a sacred place for believers of Hindu faith. The investigated area lies between latitudes $27^{\circ} 14^{\prime}$ and $27^{\circ} 17^{\prime} \mathrm{N}$ and longitudes $77^{\circ} 17^{\prime}$ and $78^{\circ} 12^{\prime} \mathrm{E}$ and covers about 3339 sq. $\mathrm{Km}$. The average monthly maximum temperature varying between about $36^{\circ} \mathrm{C}$ and $47^{\circ} \mathrm{C}$ in summer and $25^{\circ} \mathrm{C}$ and $32^{\circ} \mathrm{C}$ in winter, and annual rainfall is $826 \mathrm{~mm}$. The study region falls in the Survey of India toposheet no 54E and 54I. The only drainage in the area is the Yamuna river which enters the area from the north and after following a meandering course is passed out of the area in the SSE direction into the Agra distract. The persistent problem of high salinity and concentrations of other chemicals in groundwater is reported in previous studies (CGWB, 2012). Physiographically the region is divided into older and newer alluvial plains. The older alluvial plains are flat to gently undulating alluvial tracts. In the marginal tracts of Yamuna in the southern part, badlands and ravenous tracts are developed. Major soil types are silty, sandy and loamy soils. According to Central Ground Water Board, India, there are 61456 tube wells and borewells reported in this region. During pre-monsoon periods the water is 2.65 to $14.34 \mathrm{~m}$ below ground level (bgl)and during post-monsoon, the levels are between 1.33 to $14.0 \mathrm{~m} \mathrm{bgl} \mathrm{(CGWB,} \mathrm{2012).}$

The geology of the study area is covered with the homogenous formation and does not show any significant structural complications. The litho-unit met within the area has been tentatively grouped under Kaimur Formation and is delivered at a lower place: Quaternary alluvium consisting of mainly sands of various grade silt, clay and kankar except for a few NE- SW trending ridges, which expose the Delhi Super Group of rocks in the west (Table 1). 


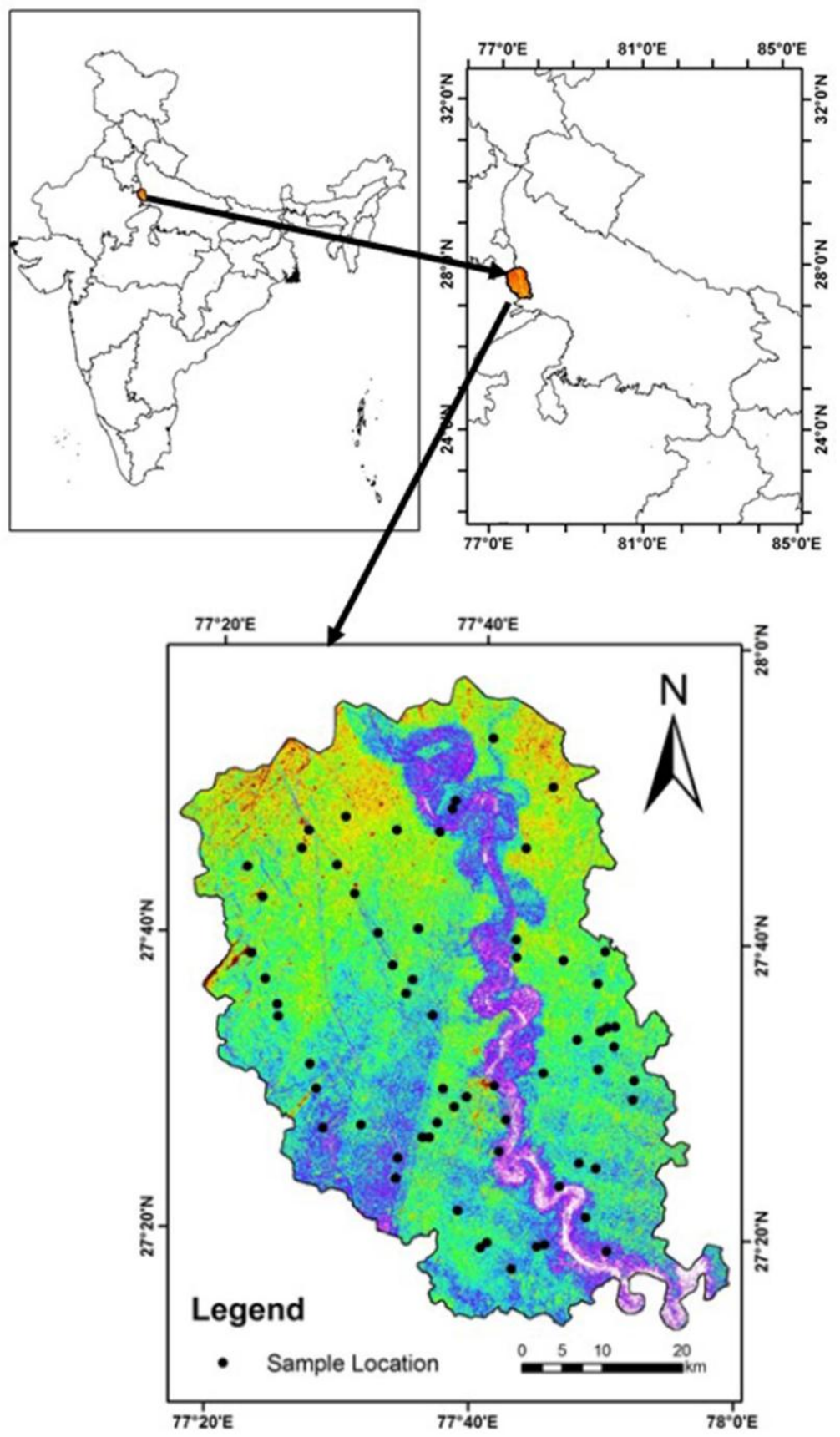

Figure 1:-Location of study area and sites of groundwater samples collected for analytical analysis in Mathura district, India.

Table.1: Generalized geological succession of the study area (GSI 2006)

\begin{tabular}{|c|l|l|l|}
\hline Group & \multicolumn{1}{|c|}{ Age } & \multicolumn{1}{c|}{ Formation } & \multicolumn{1}{c|}{ Lithology } \\
\hline Quaternary & Holocene & $\begin{array}{l}\text { Yamuna Recent } \\
\text { Alluvium }\end{array}$ & $\begin{array}{l}\text { Coarse grained, quartzo-feldspathic sand reddish } \\
\text { in colour, occur in patches in the western part } \\
\text { and micaceous grey sand. } \\
\text { composed of grey micaceous sand, clay and over } \\
\text { bank silt. }\end{array}$ \\
& & $\begin{array}{l}\text { Yamuna Terrace } \\
\text { Alluvium }\end{array}$ & \\
\hline
\end{tabular}




\begin{tabular}{|l|l|l|l|}
\hline \multirow{2}{*}{} & \multicolumn{2}{|c|}{$\begin{array}{l}\text { Mathura Older } \\
\text { Alluvium }\end{array}$} & $\begin{array}{l}\text { composed of a multicyclic sequence of clay, silt } \\
\text { and sand with calcrete. }\end{array}$ \\
\cline { 2 - 4 } & $\begin{array}{l}\text { Middle to Late } \\
\text { Pleistocene }\end{array}$ & $\begin{array}{l}\text { Older Alluvium } \\
\text { (Varanasi Alluvium) }\end{array}$ & $\begin{array}{l}\text { Oxidised, Khaki to brownish yellow silt, clay } \\
\text { with kankar disseminations, and grey to brown } \\
\text { fine to medium grained sand }\end{array}$ \\
\hline \multicolumn{2}{|c|}{ Proterozoic-III } & $\begin{array}{l}\text { Vindhyan } \\
\text { Supergroup }\end{array}$ & $\begin{array}{l}\text { Upper Bhander sandstone, } \\
\text { Quartzite, Phyllite and shale Group. }\end{array}$ \\
\hline
\end{tabular}

\section{Methodology:-}

Groundwater samples for 65 locations were collected from government hand pumps from different parts of Mathura district. Analysis of ions was carried out on the basis of methods given by APHA (American Public Health Association, 2005). Calcium $\left(\mathrm{Ca}^{2+}\right)$, total hardness $(\mathrm{TH})$, bicarbonate $\left(\mathrm{HCO}_{3}{ }^{-}\right)$and chloride $\left(\mathrm{Cl}^{-}\right)$were analysed by volumetric titration method. Sodium $\left(\mathrm{Na}^{+}\right)$level is analyzed by Systronic flame photometer (UV-VIS) model. Nitrate $\left(\mathrm{NO}_{3}{ }^{-}\right)$and sulphate $\left(\mathrm{SO}_{4}{ }^{2-}\right)$ were analysed by UV spectrophotometer. The concentration of EC is expressed in microsiemens $/ \mathrm{cm}$ at $25^{\circ} \mathrm{C}$ whereas TDS, TH, $\mathrm{Ca}^{+2}, \mathrm{Mg}^{+2}, \mathrm{Na}^{+}, \mathrm{Cl}^{-}, \mathrm{SO}_{4}, \mathrm{NO}_{3}, \mathrm{HCO}_{3}$ and $\mathrm{F}^{-}$are expressed in $\mathrm{mg}$ /1. The piper trilinear plot and USSL (sodium adsorption ratio vs conductance) diagram were plotted based on the hydrochemical results to assess the quality controlling mechanism and dominated hydro-geochemical facies of the study area. Statistical analysis was performed using the SPSS software package (SPSS, 2001). The physio-chemical parameters analysed for groundwater were compared with standard values recommended by the WHO, BIS and WQA.

ArcGIS and Surfer software were used to represent the spatial distribution maps of physio-chemical parameters. To prepare the integrated water quality map, the individual physico-chemical parameters rasters were added in the raster calculator according to the relative importance of each parameter in the overall quality of water for drinking and irrigation water purposes. The integrated water quality map is then interpreted in a GIS environment to determine the suitable ground water sites.

A land use and cover (LULC) map for the study area is generated with the help of Landsat 8 OLI image acquired on $30^{\text {th }}$ January 2016. Four classes of LULC are identified from the imagery and they are classified based on the supervised classification techniques in ENVI. The four classes identified are :i) agriculture land, ii) built-up area, iii) waterbodies and iv) wasteland/barren land.

\section{Water Quality Index:-}

WQI is one of the most effective tools to monitor the surface as well as groundwater pollution and can be used efficiently in the implementation of water quality upgrading programmes. WQI provide information on a rating scale from zero to hundred. Eleven parameters have been selected for developing the water quality index.

In the present study, the WQI has been calculated in three steps. In the first step, each of the 11 parameters (PH, TDS, $\mathrm{HCO}_{3}, \mathrm{Cl}, \mathrm{SO}_{4}, \mathrm{NO}_{3}, \mathrm{~F}, \mathrm{Ca}, \mathrm{Mg}, \mathrm{Na}$ and $\mathrm{K}$ ) has been assigned a weight $\left(\mathrm{w}_{\mathrm{i}}\right)$ according to its relative importance in the overall quality of water for drinking purposes in Table 1.

The maximum weight of five has been assigned to the parameter nitrate due to its major importance in water quality assessment. Bicarbonate is given the minimum weight of 1 as it plays an insignificant role in the water quality assessment. Other parameters like calcium, magnesium, sodium and potassium were assigned a weight between 1 and 5 depending on their importance in water quality determination. In the second step, the relative weight $\left(\mathrm{W}_{\mathrm{i}}\right)$ is computed from the following equations

$\mathrm{W}_{\mathrm{i}}=\frac{\mathrm{wi}}{\sum_{i=1}^{n} W i}$

$\mathrm{Wi}$ and wi is the relative weight and weight of each parameter, respectively, and $\mathrm{n}$ is the number of parameters. In the third step, a quality rating scale (Qi) for each parameter is assigned by dividing its concentration in each water sample by its respective standard according to the guidelines laid down in the BIS and the result for the same is multiplied by 100 (Equation 2)

$\mathrm{Q}_{\mathrm{i}}=\frac{C i * 100}{S i}$ 
where, Qi is the quality rating, $\mathrm{Ci}$ is the concentration of each chemical parameter in each water sample in mg/L. Also $\mathrm{Si}$ is the Indian drinking water standard for each chemical parameter in $\mathrm{mg} / \mathrm{L}$ according to the guidelines of the BIS.

For computing the WQI, the SI is first determined for each chemical parameter, which is then used to determine the WQI as per the following Equations (3 and 4)

$\mathrm{SI}_{\mathrm{i}}=\mathrm{W}_{\mathrm{i}} * \mathrm{Q}_{\mathrm{i}}$

Table 1:-Details of chemical parameters with their relative weight and assigned weight with drinking water standards as per BIS (2012) and WHO (2012)

\begin{tabular}{|l|l|l|l|l|}
\hline S. No. & Chemical Parameters & $\begin{array}{l}\text { Drinking water standard (7 and } \\
\text { WHO) }\end{array}$ & Weight (wi) & $\begin{array}{l}\text { Relative weight } \\
\left(\mathrm{W}_{\mathrm{i}}\right)\end{array}$ \\
\hline 1. & TDS & 500 & 5 & 0.1190 \\
\hline 2. & Bicarbonate & 244 & 1 & 0.0238 \\
\hline 3. & Chloride & 250 & 5 & 0.1190 \\
\hline 4. & Sulphate & 200 & 5 & 0.1190 \\
\hline 5. & Nitrate & 45 & 5 & 0.1190 \\
\hline 6. & Fluoride & 1.0 & 5 & 0.1190 \\
\hline 7. & Calcium & 75 & 3 & 0.0714 \\
\hline 8. & Magnesium & 30 & 3 & 0.0714 \\
\hline 9. & Sodium & 200 & 4 & 0.0952 \\
\hline 10. & Potassium & 8 & 2 & 0.0476 \\
\hline 11. & pH & 7.5 & 4 & 0.0952 \\
\hline
\end{tabular}

Table 2:-Range of water quality index specified for drinking water used in India

\begin{tabular}{|l|c|l|}
\hline S. No. & WQI range & Water Quality \\
\hline 1. & $<50$ & Excellent water \\
\hline 2. & $50-100$ & Good water \\
\hline 3. & $100-200$ & Poor water \\
\hline 4. & $200-300$ & Very poor water \\
\hline 5. & $>300$ & Water unsuitable for drinking purpose \\
\hline
\end{tabular}

where $\mathrm{SI}_{i}$ is the sub-index of the ith parameter, $\mathrm{Q}_{\mathrm{i}}$ is the rating based on the concentration of $\mathrm{i}^{\text {th }}$ parameter, $\mathrm{n}$ is the number of parameters.

The computed WQI values are categorized into five types as "excellent water" to "water, unsuitable for drinking". The range for WQI for drinking purpose is tabulated in Table 2.

\section{Result and discussions:-}

Table 3 shows the tabulated statistical parameters like maximum, minimum and mean

\section{Electrical conductivity (EC):-}

Electrical conductivity, the measure of water capacity to convey the electrical current is one of the important physiochemical parameters determining the water quality. The highest desireable limit of EC in drinking water is 750 $\mu \mathrm{S} / \mathrm{cm}$ (WHO 2016). The observed value of EC in water samples is between 900 and $14400 \mu \mathrm{S} / \mathrm{cm}$ with a mean of $3943 \mu \mathrm{S} / \mathrm{cm}$. EC represents the ability of the water to conduct electric current in which higher EC indicates enrichment of salts in the groundwater (Logeshkumaran et al. 2015). According to Sarath Prasanth et al. (2012), EC in water can be classified in to three types: type I $(\mathrm{EC}<1,500 \mu \mathrm{S} / \mathrm{cm})$; type II (EC: 1,500 and $3,000 \mu \mathrm{S} / \mathrm{cm})$; and type III $(\mathrm{EC}>3,000 \mu \mathrm{S} / \mathrm{cm})$. Based on this classification of EC, $55 \%$ of the analysed groundwater samples falling under the type III (high enrichment of salts), $27 \%$ of the samples falling under the type II (medium enrichment of salts), and $18 \%$ of the samples under the type I (low enrichment of salts).

\section{Total Dissolved Solids (TDS):-}

Total dissolved solids, the concentration of total inorganic salts and a small amount of organic salts dissolved in the water is another important physio-chemical parameter determining the water quality. TDS in groundwater samples ranges from $848 \mathrm{mg} / 1$ to $17172 \mathrm{mg} / 1$ with a mean of $4963 \mathrm{mg} / \mathrm{lin} 65$ samples. However, the desirable limit of TDS 
in water for drinking as prescribed by WHO (2006) and BIS (2012) is 500mg/l. All the 65 samples collected in this study area are higher than the permissible limit indicating severe contamination and health threat. Based on Todd (1980), about 87 percent of groundwater is classified as brackish (TDS between 1000 to $10000 \mathrm{mg} /$ ), about 12 percent is saline $(10,000$ to $1,000,000 \mathrm{mg} / \mathrm{l})$ and less than 1 percent fresh water (TDS $<1000 \mathrm{mg} /)$

\section{Sodium, Calcium and Magnesium:-}

Sodium, the dominant substances in general water has a permissible limit of $200 \mathrm{mg} / \mathrm{l}$ according to the WHO standards. The concentration of $\mathrm{Na}+$ in the collected samples ranges from $45 \mathrm{mg} / \mathrm{l}$ to $2200 \mathrm{mg} / \mathrm{l}$ with a mean value of $562 \mathrm{mg} / \mathrm{l}$. More than 86 per cent of samples lies above the prescribed limit. The high concentrations may be due to the deposition of salts from silicate bearing minerals as well as from fertilizers. The values of calcium range from $4.8 \mathrm{mg} / \mathrm{l}$ to $881.2 \mathrm{mg} / \mathrm{l}$ with a mean value of $82.5 \mathrm{mg} / \mathrm{l}$ (Table 2). Less than 11 per cent of samples are above the permissible limit prescribed by WHO (200mg/l). Magnesium concentration is very high in the groundwater samples. Observed data shows most parts of the study area have value in the non-permissible category ( $>30 \mathrm{mg} / \mathrm{l})$. It ranges from $31.2 \mathrm{mg} / \mathrm{l}$ to $1013 \mathrm{mg} / \mathrm{l}$ with a mean of $268.1 \mathrm{mg} / \mathrm{l}$.

\section{Total Hardness (TH):-}

Total hardness is one of the most important parameters in water quality assessment. It is calculated using the following equation (Sawyer et al. 2003):

$$
\mathrm{TH}\left(\text { as } \mathrm{CaCO}_{3}\right) \mathrm{Mg}=\mathrm{Ca}^{2^{+}}+\mathrm{Mg}^{2^{+}}\left(\frac{m e q}{l}\right) \times 50
$$

The TH in the study area varies between 180 to 4700 with a mean value of $1306 \mathrm{mg} / \mathrm{l}$. The WHO standards for TH is $500 \mathrm{mg} / \mathrm{l}$ suggesting 80 per cent of water samples collected are undesirable for drinking.

\section{Bicarbonate, Sulphate, Nitrate and Chloride:-}

In general, bicarbonate ion concentration in water are due to chemical dissolution of carbonate rocks and some parts dissolved $\mathrm{CO}_{2}$ in rain water. The concentration of $\mathrm{HCO}_{3}$ is observed from $39 \mathrm{mg} / \mathrm{l}$ to $1027 \mathrm{mg} / \mathrm{l}$, with a mean value of $465.5 \mathrm{mg} / \mathrm{l}$ that exceeds the maximum permissible limit $(200 \mathrm{mg} / \mathrm{l})$. Sulphate is derived mainly from the sulphide minerals present in igneous and metamorphic rocks. Anhydrites in sedimentary rocks also contribute to sulphate ion. The value of sulphate in the study area varies from $5.1 \mathrm{mg} / \mathrm{l}$ to $2237 \mathrm{mg} / \mathrm{l}$, with more than half (61\%) of the analyzed samples exceeding the permissible limit $(200 \mathrm{mg} / \mathrm{l})$. Nitrate in groundwater is mainly contributed from the decay of organic matter, sewage waste and application of fertilizers. The value ranges from $0 \mathrm{mg} / \mathrm{l}$ to $149.32 \mathrm{mg} / \mathrm{l}$. Chloride salts are highly soluble and free from a chemical reaction with the mineral of reservoir rock and remain in the form of sodium chloride. High concentration of chloride indicates a higher degree of organic pollutant. The maximum permissible limit given by WHO (2006) is $250 \mathrm{mg} / \mathrm{l}$. The value ranges from1 $14 \mathrm{mg} / \mathrm{l}$ to $3905 \mathrm{mg} / \mathrm{l}$.

Table 3:-Range of the concentration of elements in groundwater samples and their comparison with drinking water standards.

\begin{tabular}{|c|c|c|c|c|c|c|c|c|c|c|}
\hline $\begin{array}{l}\text { Parameter } \\
\text { S }\end{array}$ & \multicolumn{2}{|c|}{ BIS 2012} & $\begin{array}{r}\text { WHO } \\
2006\end{array}$ & $\begin{array}{l}\text { Mi } \\
\text { n }\end{array}$ & Max & $\begin{array}{l}\text { Mea } \\
\text { n }\end{array}$ & $\begin{array}{l}\text { Media } \\
\text { n }\end{array}$ & $\begin{array}{l}\text { Skewnes } \\
\text { S }\end{array}$ & $\begin{array}{l}\text { Kutosi } \\
\text { s }\end{array}$ & $\begin{array}{l}\text { Std. } \\
\text { Dev. }\end{array}$ \\
\hline & $\begin{array}{l}\text { Desirabl } \\
\text { e } \\
\text { limit } \\
(\mathrm{mg} / \mathrm{l})\end{array}$ & $\begin{array}{l}\text { Max. } \\
\text { Permissibl } \\
\text { e } \\
\text { Limit } \\
(\mathrm{mg} / \mathrm{l})\end{array}$ & $\begin{array}{l}\text { Highest } \\
\text { desirabl } \\
\mathrm{e} \\
\text { limit } \\
(\mathrm{mg} / \mathrm{l})\end{array}$ & & & & & & & \\
\hline $\mathrm{Ec}(\mu \mathrm{S} / \mathrm{cm})$ & - & - & 750 & 900 & 14400 & 3943 & 3500 & 1.51 & 2.44 & 2857 \\
\hline TDS & 500 & 2000 & 500 & 848 & 17172 & 4963 & 3736 & 1.34 & 1.76 & 3785 \\
\hline $\mathrm{Ca}$ & 75 & 200 & 75 & 4.8 & 881.2 & 82.5 & 32.1 & 3.8 & 16.39 & $\begin{array}{r}147 . \\
2\end{array}$ \\
\hline $\mathrm{Na}$ & - & 200 & 200 & 45 & 2200 & 562 & 410 & 1.83 & 3.53 & $\begin{array}{r}437 . \\
6\end{array}$ \\
\hline $\mathrm{Mg}$ & 30 & 100 & 30 & $\begin{array}{r}31 . \\
2\end{array}$ & 1013 & 268.1 & 220.3 & 1.43 & 0.52 & 197 \\
\hline $\mathrm{TH}$ & 200 & 600 & 500 & 180 & 4700 & 1306 & 1000 & 1.3 & 1.44 & 985 \\
\hline $\mathrm{HCO}_{3}$ & 200 & 600 & 200 & 39 & 1027 & 465.8 & 481 & 0.27 & 0.03 & $\begin{array}{r}201 . \\
6\end{array}$ \\
\hline
\end{tabular}




\begin{tabular}{|l|r|r|r|r|r|r|r|r|r|r|}
\hline $\mathrm{SO}_{4}$ & 200 & 400 & 200 & 5.1 & 2237 & 437.1 & 273.9 & 1.94 & 5.08 & $\begin{array}{r}410 . \\
8\end{array}$ \\
\hline $\mathrm{NO}_{2}$ & 45 & $\begin{array}{l}\text { No } \\
\text { Relaxation }\end{array}$ & 50 & 0 & 149.3 & 19.85 & 8.2 & 2.81 & 7.09 & 35.0 \\
9 \\
\hline $\mathrm{Cl}$ & 250 & 1000 & 250 & 114 & 3905 & 1083 & 852 & 1.48 & 1.5 & 972 \\
\hline
\end{tabular}

Table 4:-Water Quality Index of the Study Area

\begin{tabular}{|c|c|c|c|}
\hline S.No & sample name & WQI & Water Quality \\
\hline 1 & RAYA 2, Raya Block & 981.444 & Water unsuitable for drinking purpose \\
\hline 2 & NAURANGIA JAGATIYA & 725.54 & Water unsuitable for drinking purpose \\
\hline 3 & Village Usfar, Mathura block & 366.193 & Water unsuitable for drinking purpose \\
\hline 4 & NAGLA JHARELA, Nandgaon Block & 737.385 & Water unsuitable for drinking purpose \\
\hline 5 & KHUMA, Raya Block & 117.852 & poor water \\
\hline 6 & Goverdhan 2, Goverdhan Block & 323.229 & Water unsuitable for drinking purpose \\
\hline 7 & FARAH B.D.O, Farah Block & 369.497 & Water unsuitable for drinking purpose \\
\hline 8 & BERI, Farah Block & 326.92 & Water unsuitable for drinking purpose \\
\hline 9 & FALLIN, Chhatta Block & 618.13 & Water unsuitable for drinking purpose \\
\hline 10 & SIMANA, Raya Block & 1081.96 & Water unsuitable for drinking purpose \\
\hline 11 & MATHURA REFINERY, Mathura & 279.902 & Very poor water \\
\hline 12 & Village PALSON, Goverdhan Block & 282.978 & Very poor water \\
\hline 13 & AAJAI KHURD, Chaumauhan Block & 146.342 & poor water \\
\hline 14 & AKBARPUR,Chaumauhan Block & 197.81 & poor water \\
\hline 15 & HARIPUR, Nandgaon Block & 237.563 & Very poor water \\
\hline 16 & SERSHA, Farah Block & 264.195 & Very poor water \\
\hline 17 & JAMALPUR, Farah Block & 296.649 & Very poor water \\
\hline 18 & SURIR KALAN, Matt Block & 265.53 & Very poor water \\
\hline 19 & Village Mukdumpur, Mathura block & 143.484 & poor water \\
\hline 20 & Village NEEMGAON, Goverdhan Block & 965.2044 & Water unsuitable for drinking purpose \\
\hline 21 & PIRSUA, Raya Block & 291.399 & Very poor water \\
\hline 22 & BEHRANA, Raya Block & 284.62 & Very poor water \\
\hline 23 & NEEMGAON, Matt Block & 570.324 & Water unsuitable for drinking purpose \\
\hline 24 & BAZZNA, Naujhil Block & 152.296 & poor water \\
\hline 25 & NAGLA SAJNA, Baldeo Block & 842.804 & Water unsuitable for drinking purpose \\
\hline 26 & Village Paintha, Goverdhan Block & 1105.697 & Water unsuitable for drinking purpose \\
\hline 27 & RAHEEMPUR, Farah Block & 262.646 & Very poor water \\
\hline 28 & YAMUNA RIVER, Mathura City & 199.821 & poor water \\
\hline 29 & JABRA, Matt BLOCK & 398.659 & Water unsuitable for drinking purpose \\
\hline 30 & DAULATPUR, Baldeo Block & 285.865 & Very poor water \\
\hline 31 & JAIT, Mathura Block & 576.022 & Water unsuitable for drinking purpose \\
\hline 32 & Village SONKH1, Goverdhan Block & 1216.945 & Water unsuitable for drinking purpose \\
\hline 33 & HABEEBPUR, Baldeo Block & 458.567 & Water unsuitable for drinking purpose \\
\hline 34 & BALDEO B.D.O, Baldeo Block & 316.181 & Water unsuitable for drinking purpose \\
\hline 35 & HASANPUR, Naujhil Block & 114.0382 & poor water \\
\hline 36 & Village Usfar, Mathura block & 1004.6857 & Water unsuitable for drinking purpose \\
\hline 37 & Village LALPUR, Goverdhan Block & 582.3094 & Water unsuitable for drinking purpose \\
\hline 38 & GIDOH, Nandgaon Block & 602.5946 & Water unsuitable for drinking purpose \\
\hline 39 & MAKDOOMPUR,Naujhil Block & 627.86 & Water unsuitable for drinking purpose \\
\hline 40 & SHERGARH 1,Chhatta Block & 710.8197 & Water unsuitable for drinking purpose \\
\hline 41 & NANDGAON, Nandgaon Block & 879.5286 & Water unsuitable for drinking purpose \\
\hline 42 & Village SON, Goverdhan Block & 322.6682 & Water unsuitable for drinking purpose \\
\hline 43 & MATT 1,Matt Block & 500.943 & Water unsuitable for drinking purpose \\
\hline 44 & CHARMARPUR, Baldeo Block & 201.611 & Very poor water \\
\hline 45 & MATHURA B.D.O, Mathura Block & 200.29 & Very poor water \\
\hline 46 & NARISEMRI,Chaumauhan Block & 677.912 & Water unsuitable for drinking purpose \\
\hline
\end{tabular}




\begin{tabular}{|l|l|l|l|}
\hline 47 & NUNERA, Raya Block & 625.381 & Water unsuitable for drinking purpose \\
\hline 48 & KOSHI, Nandgaon Block & 409.855 & Water unsuitable for drinking purpose \\
\hline 49 & SHAHPUR, Raya Block & 204.8031 & Very poor water \\
\hline 50 & BIJAULI, Matt Block & 122.718 & poor water \\
\hline 51 & GOHARI, Chhatta Block & 442.32 & Water unsuitable for drinking purpose \\
\hline 52 & CHHATTA, Chhatta Block & 374.4448 & Water unsuitable for drinking purpose \\
\hline 53 & HOTHODA, Baldeo Block & 334.6781 & Water unsuitable for drinking purpose \\
\hline 54 & PAIGAON, Chhatta Block & 204.2002 & Very poor water \\
\hline 55 & CHAUMAUHAN B.D.O,Chaumauhan Block & 1058.781 & Water unsuitable for drinking purpose \\
\hline 56 & NAGLA BHARAU, Raya Block & 184.3115 & poor water \\
\hline 57 & CHHINPARI, Naujhil Block & 200.7081 & Very poor water \\
\hline 58 & Sabji mandi (near goverdhan chaurah ) Mathura & 398.5853 & Water unsuitable for drinking purpose \\
& block & & \\
\hline 59 & ANDUA, Matt Block & 450.484 & Water unsuitable for drinking purpose \\
\hline 60 & BARSANA,Nandgaon Block & 208.4814 & Very poor water \\
\hline 61 & TARAULI JANVI,Chaumauhan Block & 644.583 & Water unsuitable for drinking purpose \\
\hline 62 & Village Palikhera, Mathura block & 377.556 & Water unsuitable for drinking purpose \\
\hline 63 & HUSSAINEE,Chhatta Block & 185.2743 & poor water \\
\hline 64 & SHEHI, Goverdhan Block & 393.3627 & Water unsuitable for drinking purpose \\
\hline 65 & SATOHA, Mathura Block & 344.5894 & Water unsuitable for drinking purpose \\
\hline
\end{tabular}

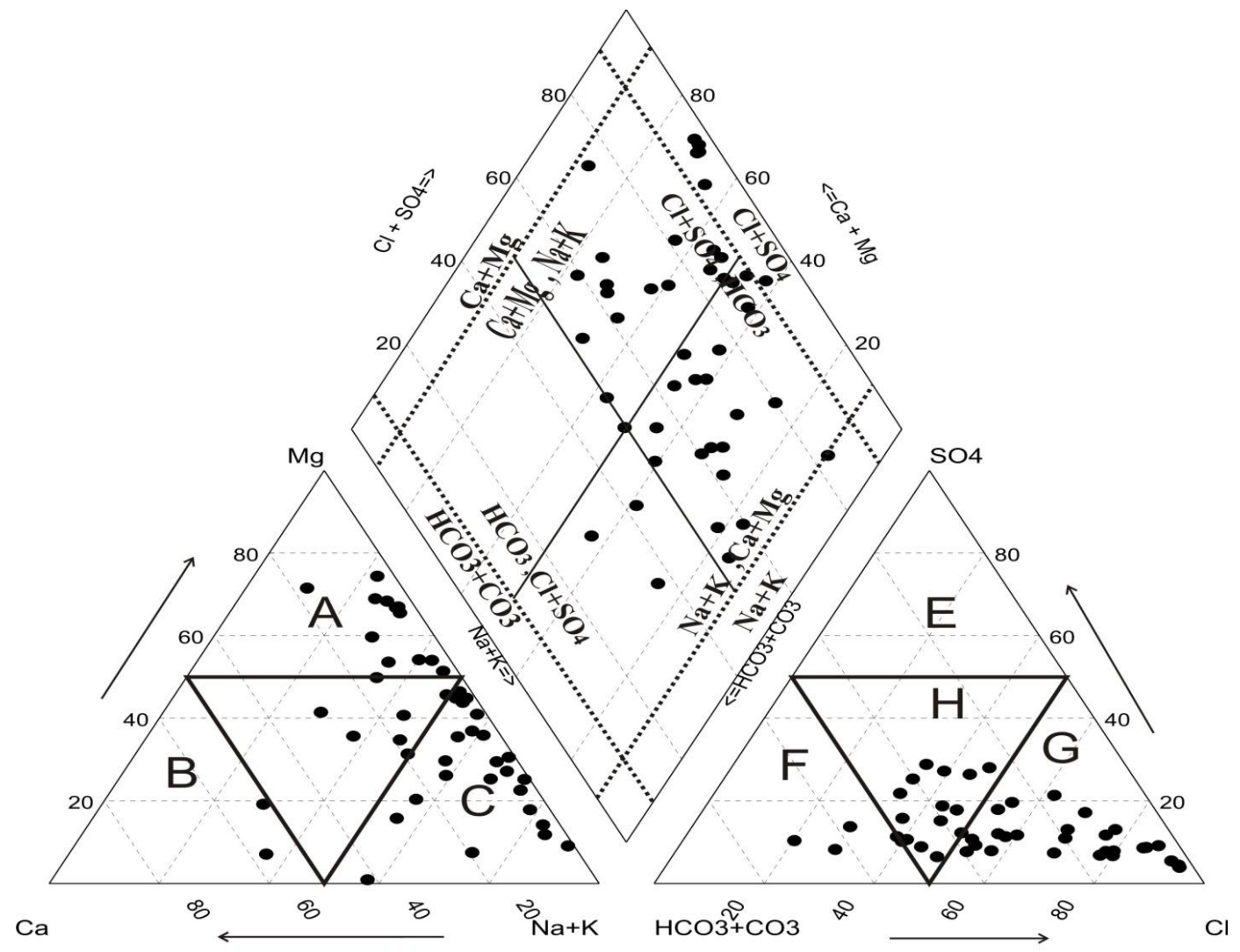

\section{CATION FACIES}

A. Magnesium type

B. Calcium type

C. Sodium or Potassium type

D. No Dominant type

\section{ANIONS FACIES}

E. Sulphate type

F. Bicarbonate type

G. Chloride type

H. No Dominant type

Figure 2:-Piper Trilinear Diagram. Showing different hydrochemical facies. 


\section{Piper trilinear diagram:-}

Piper plots (also known as Piper trilinear diagrams) are robust tools for visualizing the relative abundance of common ions present in groundwater (Piper A.M., 1953). The piper plots are explained using the facies classification of Back and Hanshaw (1965). It has been extensively used in groundwater hydrology in order to determine whether water is suitable for human consumption. Differences and similarities within groundwater samples can be identified from the trilinear plot, because the water of similar qualities will the occupy same space as groups. For plotting the diagram, sample concentrations are normalized to 100 (sum of cations = 100; and the sum of anions $=100$ ), for calculations to be made on a percentage basis. The plots in figure 2 show that the alkali concentrations are abundant constituting $71 \%$ of cations; whereas $10 \%$ of samples exhibit no dominant character. Calcium represents $3 \%$ of the samples; and $16 \%$ are comprised of magnesium type. About $75 \%$ of the samples exhibit chloride, $21 \%$ of the total samples shows no dominant character and $4 \%$ of the sample are rich in sulphate anions. Interpretation of diamond plots indicates sodium chloride waters and calcium sulfate waters dominate the study region followed by a small percent of sodium bicarbonate waters.

\section{USSL Diagram:-}

The quality of water for irrigation purpose can be tested using the sodium adsorption ratio (SAR). It is an indicator of the suitability of the water for agricultural irrigation, as it quantifies the amount of sodium relative to calcium and magnesium in the water. The US Salinity Laboratory classification for classification of ground water is shown in Figure 3. This diagram plots SAR against the conductance. The data plotted on the USSL Diagram in Figure 3 illustrates that most of the groundwater samples fall in the field of C3S1, C4S3 and C4S2 indicating high to very high salinity and low to high sodium water type which can be unsuitable for irrigation purposes.

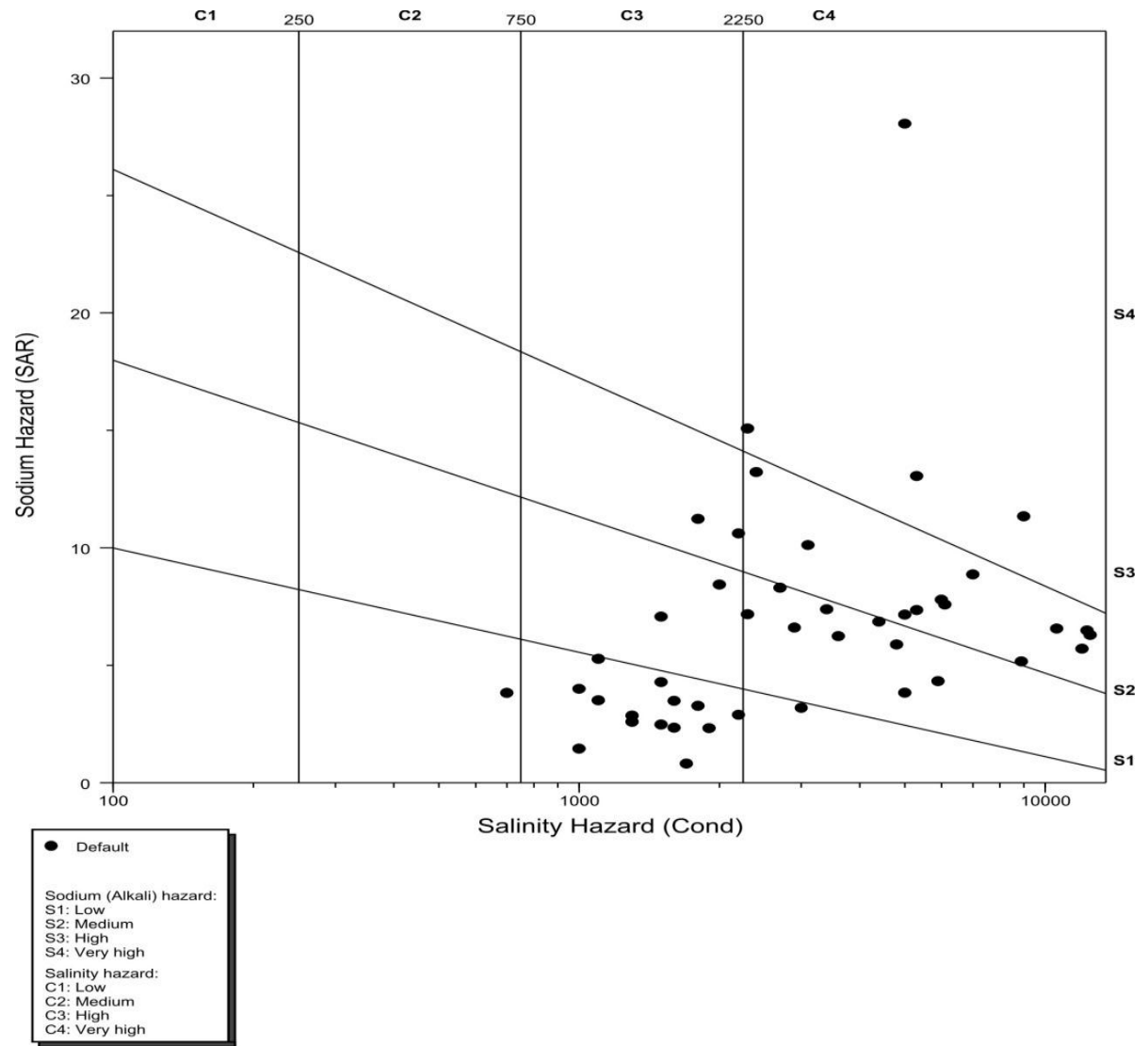

Figure 3:-Electrical conductivity Vs Sodium Absorption Ratio (USSL, 1954) diagram showing the quality of water drinking and irrigation purpose.

LULC Map:-

Figure 4 shows the land use and cover prepared from Landsat 8 OLI image using a supervised classification technique. More than $78 \%$ of the study area falls under the agriculture land category. Wasteland (barren) accounts 
for $6 \%$ of the Mathura district. Surface water bodies occupies about $1 \%$ of the total area. The settlements (built-up area) which accounts for more than $14 \%$ are located largely on the banks and flood plains of Yamuna River. As seen from the LULC map and field observations, the agricultural land extracts large amounts of water for irrigation. This causes the depletion of water resources and saline intrusion. Apart from this issue, fertilizers added to these cultivated lands leach into the groundwater and pollute the aquifers.

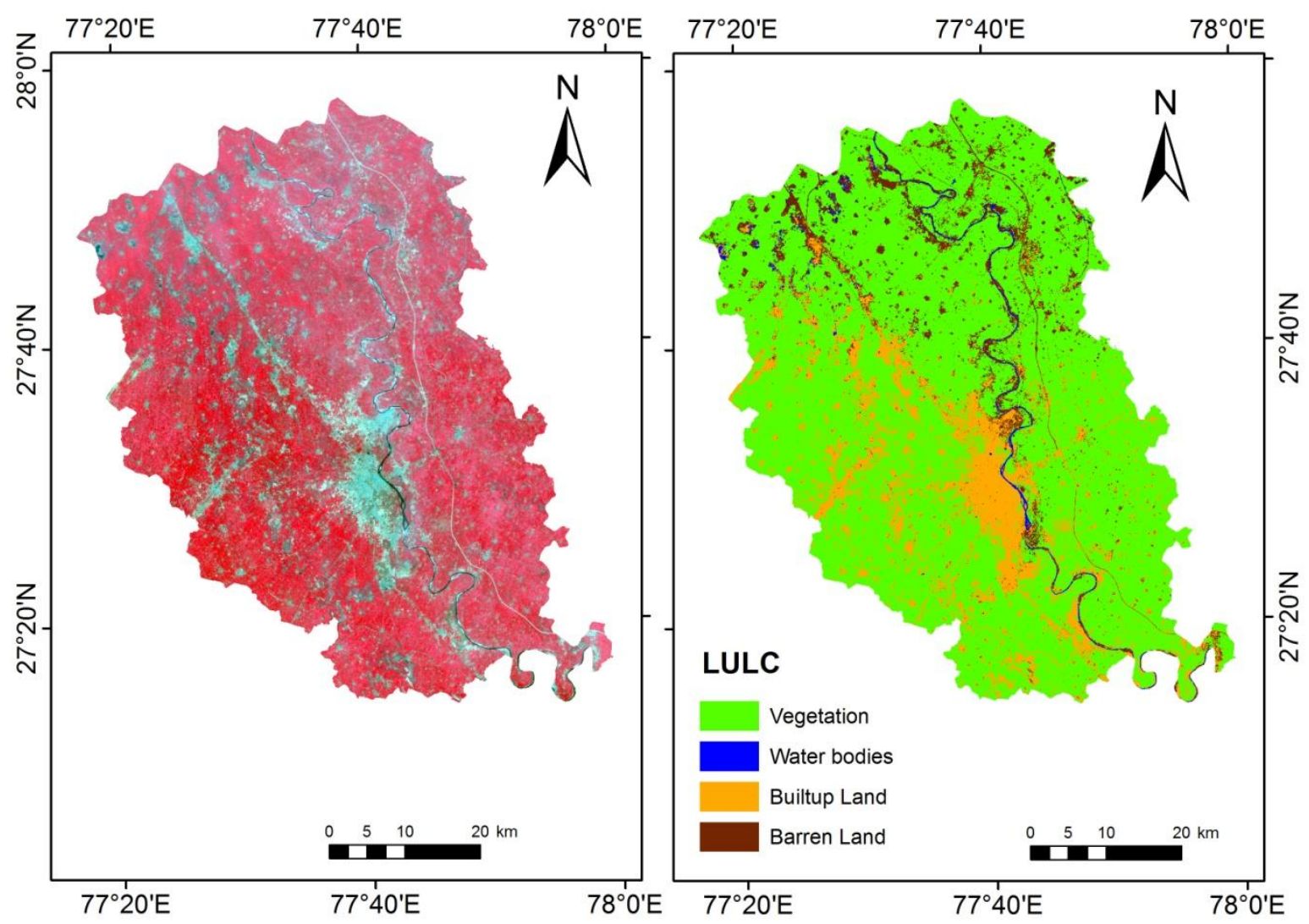

Figure 4:-Satellite imagery and land use/land cover map for the study area. Note that $78 \%$ of the area is covered with agricultural land.

\section{Spatial distribution characteristics:-}

Figure 5 shows the iso-concentration contour lines for various physio-chemical parameters analysed using inverse distance weight (IDW) interpolation in a GIS environment. Red contours show the areas above permissible limits. Large variations in nitrate concentrations are observed in Figure 5a,. The highest concentrations are noticed at the central and north Mathura blocks. Permissible limits of $\mathrm{NO}_{2}$ concentrations are observed as patches in southern and north eastern regions. Figure $4 \mathrm{~b}$ shows the spatial distribution of sulphate concentrations. Similar to $\mathrm{NO}_{2}$, sulphate are also highest at the central region with patches of permissible limits at the margins of the district boundary. The bicarbonate concentration map shown in Figure 5c suggests that except for some patches in central and sothern Mathura, most of the regions are covered under the permissible category. TH is found highest for the whole of Mathura district (Figure 5d); whereas calcium concentration is highest only in the western Mathura (Figure 5e). Similar to the TH map, sodium and magnesium are also found in the non-permissible category for the entire Mathura suggesting a severe threat to human health for those consuming these waters (Figure $5 \mathrm{f}$ and $5 \mathrm{~g}$ ). Chloride is found in higher concentrations in the western part of the City of Mathura (Figure 5h). Except for minor patches in the eastern part, electrical conductivity and TDS are found highest for large parts of Mathura district (Figure 5i and $5 \mathrm{j})$.

The integrated groundwater quality map (Figure 5k) has categorized the region into five classes on the basis of the overlay analysis applied to different features of the thematic maps. The classes are namely i) desirable for drinking and irrigation, ii) desirable for irrigation, iii) moderately desirable for irrigation, iv) low desirability for irrigation, 
and iv) undesirable. Based on the overlay analysis for desirable groundwater sources, it is found that only $2 \%$ of the area in Mathura district is desirable for extracting drinking water according to the WHO standards, $18 \%$ of area is desirable for extracting water for irrigation, $45 \%$ under moderate category, $29 \%$ occupies low desirability category and $4 \%$ in the undesirable category for the study area.

It can be observed from our study that most parts of the Mathura district in the IGB system have a high amount of TDS, and $\mathrm{Na}$ and $\mathrm{Mg}$ concentrations. The IGB alluvial aquifers are known for salinity issues (MacDonald et al. 2016). Previous studies indicated that the sodic soils of the Indo-Gangetic plain are derived from in-situ weathering of alkali aluminosilicates (Kapoor et al. 1981). It is also postulated that salt-rich geological formations have contributed to the alluvial deposits of the Ganga plain (Kumar et al.1993). Magnesium and TDS are natural constituents of aquifers and therefore chances of their origin from the anthropogenic activities is minimal. Elevated concentrations of nitrate could be explained by Figure 5. The LULC map shows a large part of the Mathura district is covered by agricultural land. Improper use of nitrogen as fertilizers in agriculture fields potentially discharge nitrates into the groundwater in Mathura and adjacent districts. High nitrate concentrations in Agra district have been reported in previous studies (UPGWD, 2017). Other sources of nitrogen inputs such as sewage effluents, natural soil, animal excreta and their dilution due to rainfall infiltration must be considered as the most relevant for the Mathura region.

As compared with previous works from others regions within the Indo-Gangetic Basin, the levels of various parameters analysed are found to be relatively high in this region. Singh et al. (2006) reported that groundwater in the northern IGB is mainly of Na-HCO3 type. Analysis of river chemistry in the upstream areas of IGB indicate dominant carbonate weathering whereas downstream is dominated by silicate weathering in the catchment indicating the trends of concentrations largely vary within the basin (Sarin et al. 1989). For example, eighteen per cent of the total 65 water samples analysed near Varanasi, India show a higher concentration of nitrate (above permissible level) (Raju et al. 2011) where as in this study about $10 \%$ samples have nitrate concentrations above the permissible limit (>45 mg/l). Umar et al. (2009) reported that more than $90 \%$ of samples analysed in the central Ganga plain show above desirable levels of TDS irrespective of the season. Thus local-scale monitoring is necessary for assessing the groundwater quality and our study pinpointed the spatial behaviour of various physio-chemical 
parameters using GIS analysis in order to quantify and graphically represent the water quality of Mathura district.
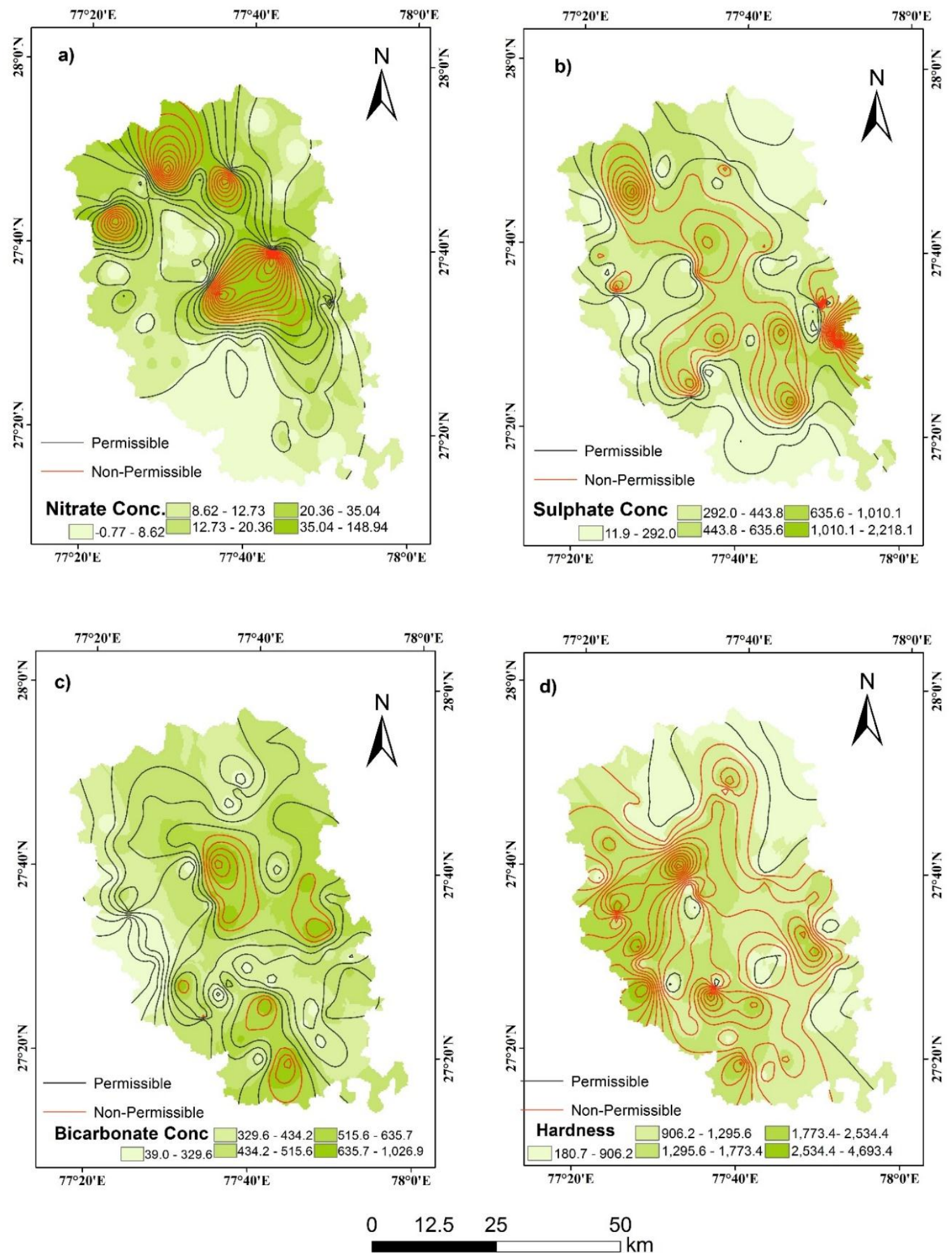

Figure 5:-Spatial distribution of iso-concentration map of various physio-chemical parameters analysed for Mathura district, India: a) Nitrate, b) Sulphate, c) Bicarbonate, d) Total Hadness 

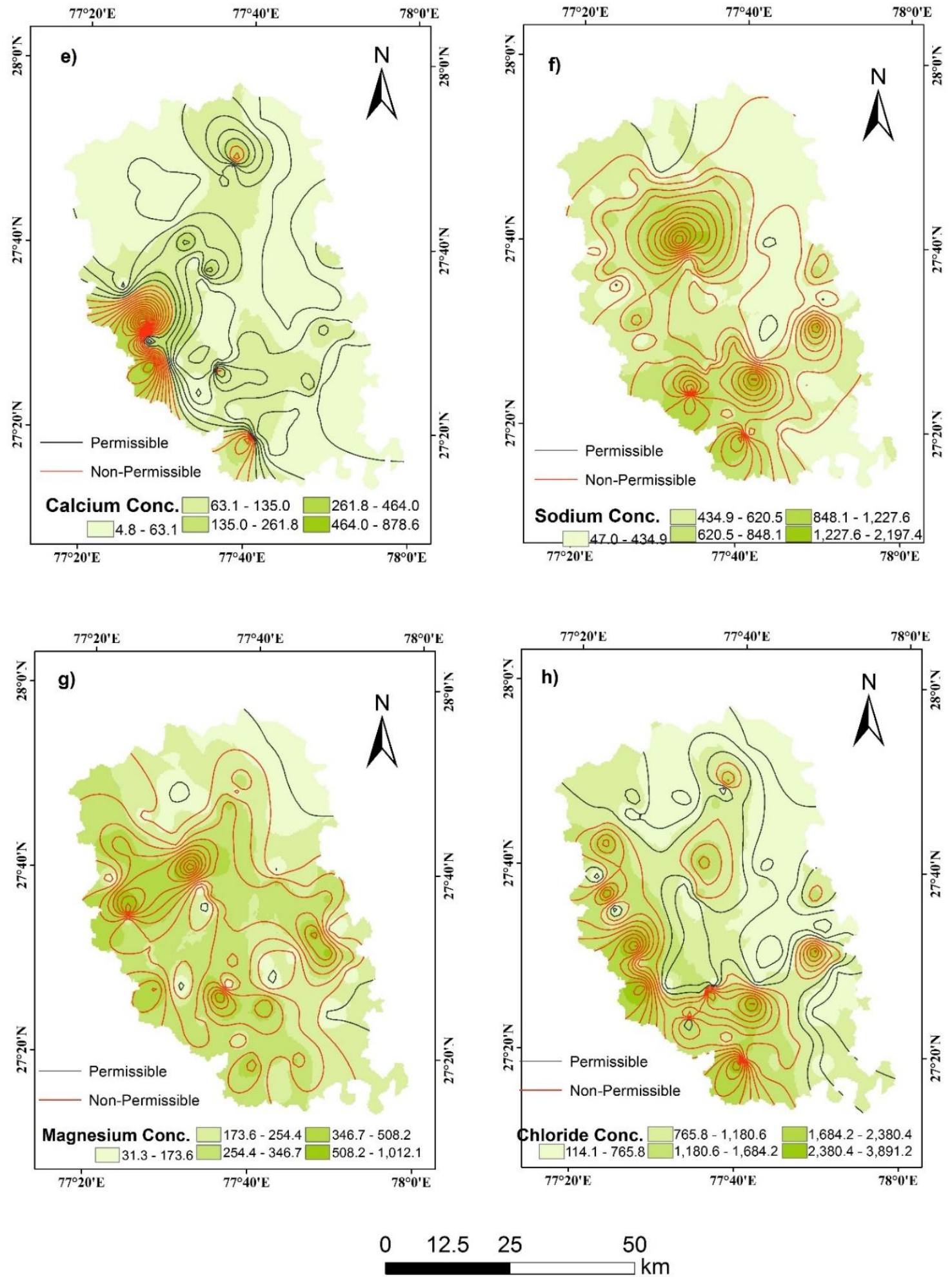

Figure 5:-continued. e) Calcium, f) Sodium, g) Magnesium, h) Chloride 

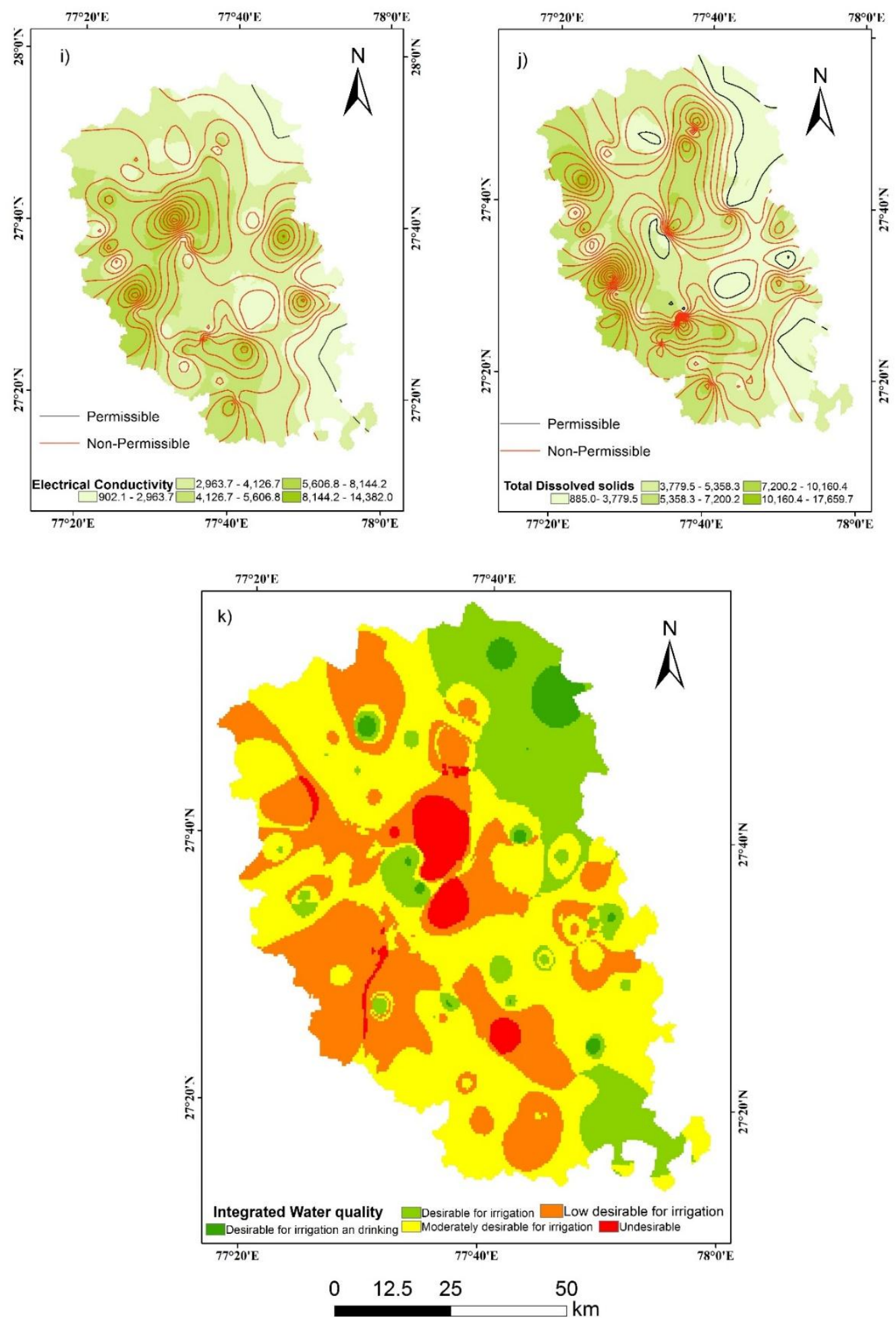

Figure 5:-CONTINUED. i) Electrical conductivity, j) Total dissolved solids and k) integrated water quality map 


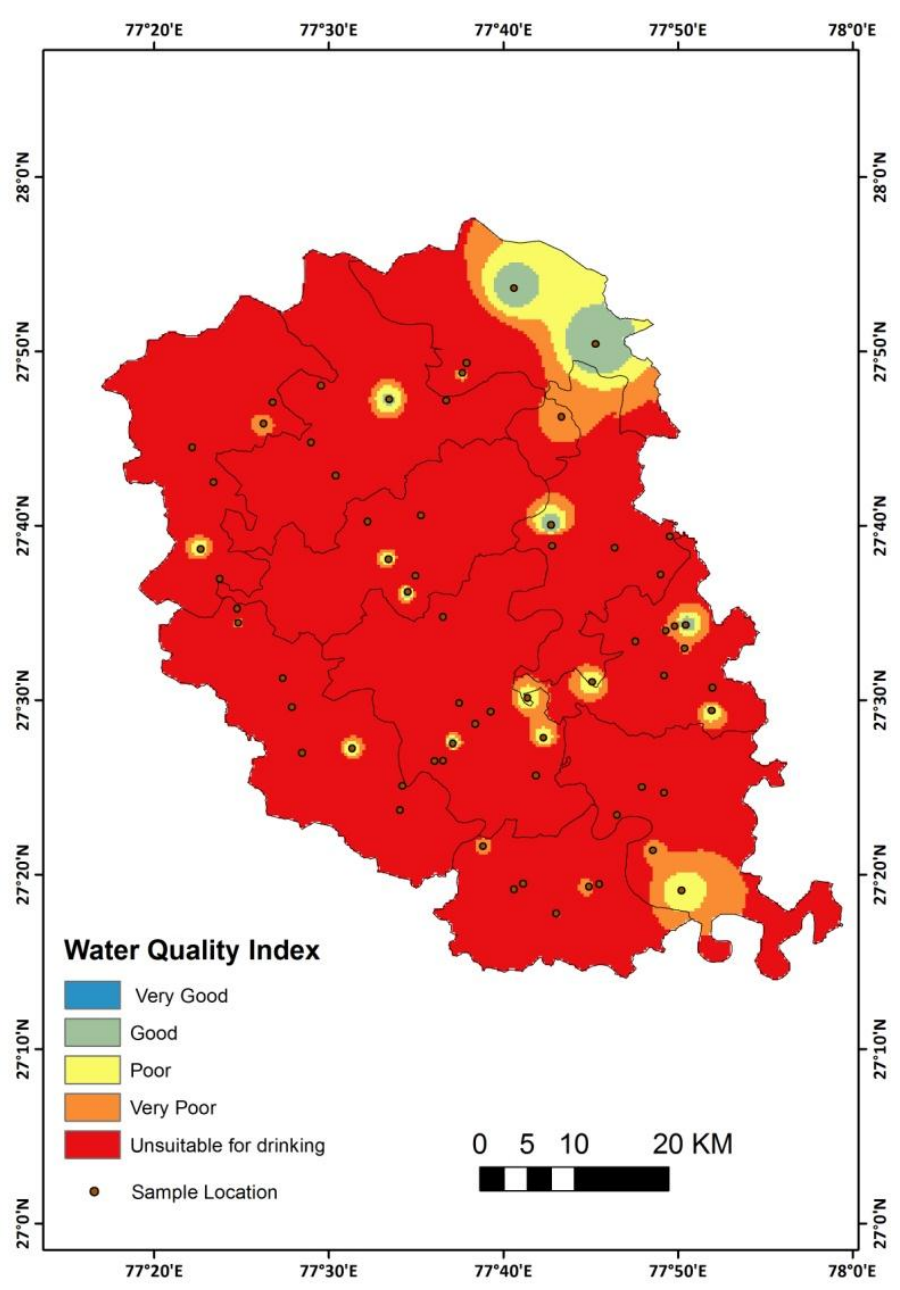

Fig 6:-Water quality index of Mathura district.

\section{Conclusion:-}

Analytical techniques coupled with GIS and remote sensing approaches have been used to identify suitable groundwater sites in Mathura district for drinking and irrigation purposes. The results show that water quality in most parts of the study area is unsuitable for drinking and irrigation. The suitable sites identified based on the spatial distribution characteristics are located at north-east and southern parts of Mathura district. The major cause of the high concentration of different water quality parameters is geogenic. The suitable groundwater zonation map generated through analytical analysis, remote sensing and GIS ascertains the applicability of coupled models and necessity of regional-scale analysis. It is suggested that proper treatment methods and measures should be implemented before consumption of the water for drinking and irrigation. Furthermore, to tackle the ground water depletion in the region, it is recommended to adapt sprinkling irrigation for proper utilization of water resources and to overcome the shortage of water faced in future. 


\section{References:-}

1. AHER, K. R., \& DESHPANDE, S. M. (2015):. Hydrogeochemical characteristics and Assessment of water quality in Dheku basin, Aurangabad, India, 17(1), 41-49.

2. APHA 2005., Standard methods for the examination of Water and Wastewater, $21^{\text {st }}$ edition, APHA, AWWA \& WPCF, Washington, D.C.

3. BIS 2012., Indian standard specifications for drinking water, B.S. 10500.

4. BHUTIANI R, KULKARNI DB, KHANNA DR, GAUTAM A (2016) : Water quality, pollution source apportionment and health risk assessment of heavy metals in groundwater of an industrial area in North India. Exposure and Health 8(1):3-18. doi: 10.1007/s12403-015-0178-2

5. BACK, W. and HANSHAW, B.(1965): Chemical Geohydrology Advances in Hydroscience (Back W. Hanshaw Beds)Academic Press, USA.

6. CHAKRABORTI, D., DAS, B., RAHMAN, M. M., CHOWDHURY, U. K., BISWAS, B., GOSWAMI, A. B.,.. \& HOSSAIN, A. (2009): Status of groundwater arsenic contamination in the state of West Bengal, India: A 20-year study report. Molecular nutrition \& food research, 53(5), 542-551.

7. DISTRICT, M.\&PRADESH,U.(2006): (final report on a Geoenvironmental appraisal of. Mathura district).

8. EL-SALAM, M. M. A., \& ABU-ZUID, G. I. (2015): Impact of landfill leachate on the groundwater quality: A case study in Egypt. Journal of advanced research, 6(4), 579- 586.

9. (UPGWD, 2017)groundwater stress-city Agra(an overview of urban aquifers and gw crises)http://upgwd.gov.in/mediagallery/ground\%20water\%20stress\%20\%e2\%80\%93\%20city\%20agra.pdf

10. HEM, J.D. (1991): Study and interpretation of the chemical characteristics of natural water: USGS Professional Paper Book 2254. Scientific Publishers, Jodhpur

11. KARANTH K. R. (1987): Groundwater assessment, development and management. Tata McGraw Hill, New Delhi, 720 .

12. Li, P. (2016):Groundwater quality in western China: challenges and paths forward for groundwater quality research in western China.

13. LOGESHKUMARAN, A., MAGESH, N. S., GODSON, P. S., \& CHANDRASEKAR, N. (2015): Hydrogeochemistry and application of water quality index (WQI) for groundwater quality assessment, Anna Nagar, part of Chennai City, Tamil Nadu, India. Applied Water Science, 5(4), 335-343.

14. MACDONALD, A. M., BONSOR, H. C., AHMED, K. M., BURGESS, W. G.,BASHARAT, M., CALOW, R. C., ... \& LARK, R. M. (2016): Groundwater quality and depletion in the Indo-Gangetic Basin mapped from in situ observations. Nature Geoscience, 9(10), 762-766.

15. MOHAN, R., SINGH, A.K., TRIPATHI, J.K. and CHAUDHARY, G.C. (2000): Hydrochemistry and quality assessment of groundwater in Naini industrial area, District Allahabad, Uttar Pradesh. Jour. Geol. Soc. India, v.55, pp.77-89

16. PIPER, A.M.(1953): A graphic procedure for the geo-chemical interpretation of water analysis, USGS Groundwater Note No .12.

17. S.P. Bhartiya (2006):"FINAL REPORT ON GEOENVIRONMENTAL APPRAISAL OF MATHURA DISTRICT, UTTAR PRADESH” GSI.

18. WHO 2006., Guidelines for drinking water quality, v1 WHO, Geneva. 